\title{
The mortality rate after hospital discharge in patients with myelomeningocele decreased after implementation of mandatory flour fortification with folic acid
}

\author{
Redução da taxa de mortalidade após a alta hospitalar em pacientes com mielomeningocele \\ depois da implementação da fortificação obrigatória das farinhas com ácido fólico \\ Renato Manganelli Salomão', Tatiana Protzenko Cervante², José Francisco Manganelli Salomão², Soniza \\ Vieira Alves Leon ${ }^{3}$
}

\begin{abstract}
Objective: To evaluate the mandatory folic acid fortification of flour on mortality rates after the hospital discharge of children born with myelomeningocele, the most affected age group and the most frequent cause of death. Methods: A retrospective study of 383 children born with myelomeningocele from January 1990 to December 2013 in a high-fetal-risk reference hospital. Results: A total of 39 patients died (10.1\%), of which $23(6 \%)$ died after discharge. Most children who died were younger than 12 months of age. The most frequent cause of death was infection of the central nervous system, followed by urinary tract sepsis and infections of the respiratory system. Symptomatic Chiari II malformation was the most frequent comorbidity factor. Conclusion: Although there was no significant difference in infant mortality before and after folic acid fortification, there was a significant reduction in deaths after hospital discharge in babies born after implementation of mandatory folic acid fortification
\end{abstract}

Keywords: meningomyelocele; mortality; folic acid.

\section{RESUMO}

Objetivo: Avaliar a fortificação obrigatória de farinhas com ácido fólico nas taxas de mortalidade após a alta hospitalar de crianças nascidas com mielomeningocele, a faixa etária mais atingida e a causa mais freqüente de morte. Métodos: Estudo retrospectivo de 383 crianças nascidas com mielomeningocele de janeiro de 1990 a dezembro de 2013, em um hospital de referência de alto risco fetal. Resultados: Um total de 39 pacientes morreram (10,1\%), dos quais 23 (6\%) morreram após a alta. A maioria das crianças que morreram não alcançaram 12 meses de idade. A causa mais frequente de morte foi infecção do sistema nervoso central, seguido por sépsis, infecções do trato urinário e do sistema respiratório. A malformação de Chiari Tipo II foi a comorbidade mais freqüente. Conclusão: Apesar de não haver diferença significativa na frequência de mortalidade de recém-nascidos, antes e depois da fortificação obrigatória com ácido fólico, houve uma redução significativa no número de mortes após a alta hospitalar em bebês nascidos após a implementação da fortificação obrigatória das farinhas com ácido fólico.

Palavras-chave: meningomielocele; mortalidade; ácido fólico.

Myelomeningocele (MMC), or spina bifida cystica, is the most common neural tube defect, developing between days 21 and 28 after fertilization ${ }^{1,2}$. The lack of a protective lining exposes the neural tissue to gradual destruction due to the deleterious effects of amniotic fluid over the neural plate ${ }^{3}$.

The prevalence of MMC varies according to the geographic, racial, and ethnic characteristics of the population being studied, and may differ greatly between different regions of the same continent or country ${ }^{4,5}$. In Brazil, the prevalence of Chiari II malformation (CMII) is estimated to range between 1.4 and 1.5 per 10,000 births ${ }^{6,7}$. The cause of MMC is multifactorial, but folic acid (FA) deficiency is the main risk factor. Chromosomal and genetic abnormalities, maternal hyperthermia during the early stages of pregnancy, use of

\footnotetext{
'Universidade Federal do Estado do Rio de Janeiro, Escola de Medicina e Cirurgia, Rio de Janeiro RJ, Brasil;

${ }^{2}$ Fundação Oswaldo Cruz (IFF/ Fiocruz), Departamento de Cirurgia Pediátrica, Setor de Neurocirurgia do Instituto Nacional da Saúde da Mulher, Criança e Adolescente Fernandes Figueira, Rio de Janeiro RJ, Brasil;

${ }^{3}$ Universidade Federal do Estado do Rio de Janeiro, Departamento de Neurologia, Rio de Janeiro RJ, Brasil;

Correspondence: Renato Manganelli Salomão; UNIRIO / Escola de Medicina e Cirurgia; Rua Silva Ramos, 32; 22290-240 Rio de Janeiro RJ, Brasil;

E-mail: renatomsal@gmail.com

Conflict of interest: There is no conflict of interest to declare.

Received 17 December 2015; Received in final form 19 April 2016; Accepted 28 September 2016.
} 
antiepileptic drugs (e.g., valproic acid), diabetes mellitus, and obesity may also be involved ${ }^{8}$.

Around $14 \%$ of the children born with MMC die before the age of five years, and the mortality rate of children with brain stem dysfunction may exceed $35 \%{ }^{9}$. The most frequent causes of death in patients with MMC include CMII-related complications; urinary tract, pulmonary, and cerebrospinal fluid infections; as well as ventricular shunt malfunction ${ }^{10}$. In Brazil, fortification of wheat and maize flour and their derivatives with FA became mandatory after 2002.

In 2006, Bol et al. ${ }^{11}$ reported significantly improved first-year survival after implementation of mandatory folic acid fortification (FAF), compared with the survival rate of children with MMC born before fortification. A significant decline in perinatal and infant mortality was also shown by Sayed et al. ${ }^{12}$ in 2008. In 2010, Blencowe et al. ${ }^{2}$ conducted a systematic review of the literature and estimated that FAF reduces the incidence of neural tube defect by $46 \%$ and expected neonatal deaths by $13 \%$.

The aim of this study was to evaluate the impact of FAF on the mortality rate of patients with MMC who underwent surgery at a pediatric hospital in Rio de Janeiro, Brazil.

\section{METHODS}

We performed a retrospective study of a cohort of 383 children diagnosed with MMC who were surgically repaired from January 1990 to December 2013. There were 39 deaths, and our focus was on the children who died after hospital discharge, which accounted for 23 out of the 39 (58.97\%) deaths.

This study was approved by the institution's Committee of Ethics in Research.

The relationship of mortality to the following variables were evaluated: age, cause of death, risk factors, postoperative complications, and gender. Data were analyzed using Epi Info, ver. 7.1.4.0 software (Centers for Disease Control and Prevention, Atlanta, USA). Results with $\mathrm{p}$ values $<0.05$ were considered significant. The period of implementation of flour fortification was calculated according to the model used by Orioli et al. ${ }^{6}$, and consisted of the sum of the 18 months elapsed from the time of publication of the decree, the three-month period for the implementation of fortified flours, and the nine months of gestation.

\section{RESULTS}

\section{Demographics}

Of the 21,310 live births between 1994 and 2013 at the Insitituo Fernandes Figueira, 10,894 (51.1\%) were boys and 10,299 (48.3\%) were girls (male/female ratio of 1.05:1). Gender-related information was not found for $0.5 \%(n=117)$ of the children. Analysis of the 330 cases of MMC showed that the proportion of female children with MMC was $56.6 \%$ ( $\mathrm{n}=187$ ) and that of male children with MMC was $43.3 \%$ ( $\mathrm{n}=143, \mathrm{p}=0.0038$ ).

The frequency of MMC before mandatory flour fortification was $1.34 \%(\mathrm{n}=172)$, while the incidence after implementation of FAF was $1.81 \%(\mathrm{n}=158)$, which was a significant increase in the incidence rate $(\mathrm{p}=0.0055)$.

\section{Surgical technique}

For all 383 MMC cases, the initial treatment was correction of the MMC according to the usual 5-layer technique. Among the 23 patients who died after hospital discharge, five patients also underwent simultaneous placement of a ventriculoperitoneal shunt.

\section{Surgical complications}

There were 28 surgical complications; the most common were infections of cerebrospinal fluid and shunt hardware (78.5\%, $\mathrm{n}=22$ ), as well as ventriculoperitoneal shunt malfunction. The complications and incidence rates are shown in Table 1.

\section{Risk factors and causes of death}

Neurogenic bladder, recurrent urinary tract infections, lower-limb paralysis; recurrent respiratory infections, chronic constipation, chronic renal failure, hydronephrosis, apneic crises, and gastroesophageal reflux disease were risk factors for mortality.

The most common causes of death were central nervous system (CNS) infections, occurring in eight of the 23 (34.7\%) fatalities after hospital discharge. Respiratory infections and sepsis of urinary tract origin were the second most common cause of death, each being a major contributing factor in $21.7 \%$ $(n=5)$ of the 23 deaths. Respiratory tract infections were also an aggravating factor in eight cases. All the cases of urinary sepsis had kidney failure. Intracranial hypertension and CMII were major contributing factors in two of 23 (8.69\%) patients. Chiari II malformation was also present and associated with death in four other cases. The cause of death of one patient was septic gastroenteritis complicated by kidney failure.

Table 1. Complications of surgical treatment.

\begin{tabular}{lcc}
\hline Variable & N & $\%$ \\
\hline Surgical procedure & 6 & 21.4 \\
Wound Infection & 3 & 10.7 \\
Intracranial hypertension* & 3 & 10.7 \\
Ventriculoperitoneal shunt (VPS) $^{*}$ & 22 & 78.5 \\
CNS Infection & 8 & 28.5 \\
VPS Infection $_{\text {VPS Malfunction }}^{\star *}$ & 7 & 25 \\
VPS Shortening $^{\star * \star}$ & 6 & 21.4 \\
\hline
\end{tabular}

CNS: central nervous system; VPS: ventriculoperitoneal shunt; * Intracranial hypertension occurred in three children not derived at MMC correction; **Three children have resultant intracranial hypertension; ${ }^{* \star *}$ Resulting in intracranial hypertension 
Nine of 23 (39.1\%) children died in the first year of life, five between the ages of two and three years, and four between the ages of one and two years. Five children died between the ages of three and 11 years (Figure). The highest number of deaths after hospital discharge occurred in female children, $60.8 \%$ ( $n=14)$, but this rate was not significant ( $p=0.981)$.

At a given moment, five live births presenting with signs and symptoms of CMII were identified, and accounted for $21.7 \%$ of the 23 children analyzed.

\section{Correlation of deaths with hospital discharge and FAF}

Of the 383 operated children, the total number of deaths was 39 (10.1\%). The deaths were classified as occurring before hospital discharge (BHD) or after hospital discharge (AHD). The BHD group, composed of 16 of the 383 (4.1\%) cases of MMC, included the children who died at younger than 30 days and those who, despite surviving the first month of life, were not discharged. The AHD group included 23 of 383 (6.0\%) children who died after hospital discharge. The mean survival period was 2.8 years, ranging from two months to 11 years.

The mortality rates before and after fortification of the BHD group and AHD and group were compared. Before fortification there were $11 \mathrm{BHD}$ deaths and 20 AHD deaths. After fortification, five BHD patients and three AHD patients died. The total number of deaths was 31 before and eight after mandatory fortification. The reduction in total number of deaths after mandatory fortification was significant $(p=0.00919)$ and the reduction in the number of AHD deaths after fortification was significant ( $p=0.0088)$, but not the number of BHD deaths $(\mathrm{p}=0.568)$. The results are shown in Table 2 .

Of the 23 children who died AHD, the highest prevalence was observed in the lumbosacral region, followed by thoracolumbar. The locations and frequencies are presented in Table 3.

\section{DISCUSSION}

There have been few studies related to late mortality in patients with MMC, particularly regarding etiology and age ranges.

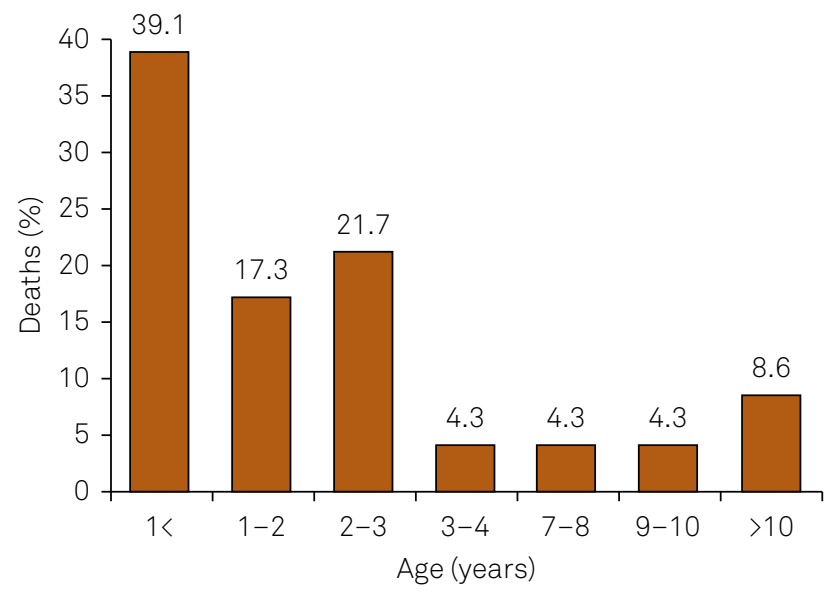

Figure. Distribution of deaths by age group.
The decrease in the incidence of MMC at our institution before and after mandatory FAF was not significant. There are several possible explanations for this finding: a) FAF of flour alone was not sufficient for promoting a significant decrease in MMC rates, because the FA concentration in Brazilian flours is $1.5 \mathrm{mg} / \mathrm{kg}$, which is lower than the FA concentration adopted by other Latin American countries, such as Argentina and Chile where the FA concentration is higher and where they have experienced a significant decrease in neural tube defects and $\mathrm{MMC}^{6,7,13}$; b) the Brazilian public health system nowadays provides easier and faster access to prenatal diagnostic tools, thereby increasing the frequency of early MMC diagnosis and directing these cases to reference centers such as the Insitituo Fernandes Figueira; c) our institution is a tertiary reference center for a low-income population, which is much more frequently affected by neural tube defects; d) Brazil is a multiracial country with an ethnic profile different from other Latin-American countries? Moreover, in some countries, the prevalence of MMC was not substantially reduced by FAF of flours, and in some countries the prevalence has even increased ${ }^{14}$. These findings might be a result of heterogeneous supplementation policies and lack of flour fortification. Also, educational and social interventions regarding folic acid supplementation are needed ${ }^{14}$.

In our series, of the 383 live births with MMC, 23 (6\%) died after hospital discharge; most of the deaths occurred before five years of age $(n=20)$, corresponding to $86.9 \%$ of the total number of AHD deaths. Analysis of deaths by age range showed that $39.1 \%(\mathrm{n}=9)$ of the children died during the first year of life. Ten deaths occurred from the ages of one to four, as follows: four (17.3\%) between one and two years, five $(21.7 \%)$ between two and three years, and one (4.3\%) between three and four years. The remaining four deaths occurred at the ages of seven $(n=1)$, nine $(n=1)$, and 11 years $(n=2)$. The highest death rates occurred in the lowest age ranges.

A Brazilian study of 36 cases of MMC found a mortality rate of $16.6 \%(n=6)$, with all the deaths occurring before two years of age ${ }^{15}$. Another study followed 84 patients after discharge, and most of the deaths $(74 \%)$ occurred during the first

Table 2. Deaths before and after mandatory flour fortification.

\begin{tabular}{lcccc}
\hline Variable & DBF $n(\%)$ & DAF n (\%) & pc & Fisher exact \\
\hline Total & $31(13.7)$ & $8(5)$ & 0.00919 & 0.00569 \\
BHD & $11(4.8)$ & $5(3.1)$ & 0.568 & 0.450 \\
AHD & $20(8.8)$ & $3(1.8)$ & 0.0088 & 0.0040 \\
\hline \multicolumn{2}{l}{ DBF: Deaths before fortification; DAF: Deaths after fortification. }
\end{tabular}

Table 3. MMC frequency according the site of the defect.

\begin{tabular}{lcc}
\hline Site & $\mathrm{n}$ & $\%$ \\
\hline Lumbosacral & 9 & 39.1 \\
Thoracolumbar & 8 & 34.8 \\
Lumbar & 5 & 21.7 \\
Thoracic & 1 & 4.3 \\
\hline
\end{tabular}


month of life ${ }^{16}$. Another case series reported that most deaths occurred between the neonatal period and preschool age ${ }^{9,17,18}$. Mortality rates in MMC do not stabilize as the patients become older. An analysis of long-term studies showed that $240(71.2 \%)$ of 337 reported deaths occurred in patients up to 16 years of age ${ }^{9,16,17,18}$. The main cause of death in patients older than 16 years was unrecognized ventriculoperitoneal shunt dysfunction ${ }^{18,19}$. A cohort study that followed patients for more than 40 years found that there were $56 \%$ of patients who survived to around 20 years of age, but the mortality rate continued to increase with age, and the last evaluation showed that there were $33.3 \%$ of patients of the initially observed population who were still alive ${ }^{9,20}$. These results are very different from those presented by Talamonti et al., who reported only five deaths among 202 patients followed over 25 years $^{21}$.

The total number of deaths in our study was 39 (10.1\%). During the period before FAF (January 1990 - December 2005), there were 225 cases of MMC, with a mortality rate of $13.7 \%$ $(\mathrm{n}=31)$. Considering only the cases in which AHD deaths occurred, the mortality rate was $8.8 \%(\mathrm{n}=20)$. After implementation of FAF, there were 158 cases of MMC, and the total death rate for this period was $5.0 \%(\mathrm{n}=8)$. There were five neonatal deaths (3.1\%) during the same period. These data show a significant reduction in the total number of deaths during the years after FAF implementation. However, regarding neonatal mortality, that is, the live births not discharged from the hospital, the mortality rate was not significantly reduced after FAF. This result differs from the findings of others on the protective role of FAF against neonatal mortality ${ }^{2,11,12}$. There was a significant decrease in AHD deaths $1.8 \%(\mathrm{n}=3)$ after implementation of mandatory FAF versus $8.8 \%(n=20)$ before implementation. A series of 304 children with MMC, who were born in Ireland before FA supplementation, showed that only $33 \%$ of the children survived to their first birthday, and just over $27 \%$ survived to the age of five years ${ }^{22}$. However, after mandatory FAF, there was a significant increase in the survival rate of children with MMC, leading to the hypothesis that FA, in addition to preventing MMC, might also play an important role in reducing the severity of MMC among live births ${ }^{1}$, as well as malformations in other organs or systems ${ }^{23}$ and the resulting neonatal mortality ${ }^{24}$.

The most common cause of death detected in our study was CNS infections, particularly those related to the cerebrospinal fluid (34.7\%), followed by urinary sepsis and respiratory infections $(21.7 \%)$. Cerebrospinal fluid infections were mostly caused by shunt infections and these are regarded as a highly significant predictor of mortality ${ }^{25}$. Children with shunts are at high risk of cerebrospinal fluid infection, ranging from $5.5 \%$ to $25 \%$ of cases $^{26}$, and shunts are thought to be the cause of death in $33 \%$ to $50 \%$ of children with $\mathrm{MMC}^{15,16}$.

Urinary tract infections resulting from neurogenic bladder and vesicoureteral reflux, in some cases, have led to urinary sepsis, kidney failure, and ultimately death ${ }^{27}$.

Chiari II malformation was the third most common cause of death, acting either as a determining or contributory factor. The signs and symptoms of this malformation are protean and may be transient, making it difficult to estimate its real prevalence among neonates and infants. It is assumed that, at some time, $6 \%$ to $32 \%$ of individuals with MMC will have neurological manifestations related to $\mathrm{CMII}^{28}$. The mortality is higher and may be the main cause of death among neonates with CMII, affecting more than $40 \%$ of MMC patients ${ }^{18,29,30}$.

Discontinuing the follow-up of patients with MMC has a dramatic impact on the number of deaths ${ }^{21,22}$. The most common cause of discontinuation is the lack of multidisciplinary centers for spina bifida treatment. Since most families have a low income and live on the outskirts of large cities, regular follow-ups are reduced or even neglected, since most patients have severe limitations in ambulation and need special requirements for transportation, which is not always available ${ }^{31}$.

In conclusion, the mortality rate of patients with MMC after they were discharged from the hospital was $6 \%$. Most children died before their first birthday. The most common causes of death were CNS infections, respiratory infections, and urinary sepsis. Symptomatic CMII was the most common comorbidity factor. The mortality rate after hospital discharge decreased after implementation of mandatory flour fortification with folic acid.

\section{References}

1. Padmanabhan R. Etiology, pathogenesis and prevention of neural tube defects. Congenit Anom (Kyoto). 2006;46(2):55-67. doi:10.1111/j.1741-4520.2006.00104.x

2. Blencowe H, Cousens S, Modell B, Lawn J. Folic acid to reduce neonatal mortality from neural tube disorders. Int J Epidemiol. 2010;39 Suppl 1:i110-21. doi:10.1093/ije/dyq028

3. Adzick NS. Fetal myelomeningocele: natural history, pathophysiology, and in-utero intervention. Semin Fetal Neonatal Med. 2010;15(1):9-14. doi:10.1016/j.siny.2009.05.002

4. Busby A, Abramsky L, Dolk H, Armstrong B. Preventing neural tube defects in Europe: population based study. BMJ. 2005;330(7491):574-5 8. doi:10.1136/bmj.330.7491.574
5

De Marco P, Merello E, Calevo MG, Mascelli S, Pastorino D, Crocetti L, et al. Maternal periconceptional factors affect the risk of spina bifida-affected pregnancies: an Italian case-control study. Childs Nerv Syst. 2011;27(7):1073-81. doi:10.1007/s00381-010-1372-y

6. Orioli IM, Lima do Nascimento R, López-Camelo JS, Castilla EE. Effects of folic acid fortification on spina bifida prevalence in Brazil. Birth Defects Res A Clin Mol Teratol. 2011;91(9):831-5. doi:10.1002/bdra.20830

7. Schuler-Faccini L, Sanseverino MTV, de Rocha Azevedo LM, Moorthie S, Alberg C, Chowdhury S, et al. Health needs assessment for congenital anomalies in middle-income countries: examining the case for neural tube defects in Brazil. J Community Genet. 2014;5(2):147-55. doi:10.1007/s12687-013-0165-x 
8. Sandler AD. Children with spina bifida: key clinical issues. Pediatr Clin North Am. 2010;57(4):879-92. doi:10.1016/j.pcl.2010.07.009

9. Oakeshott P, Hunt GM. Long-term outcome in open spina bifida. Br J Gen Pract. 2003;53(493):632-6.

10. Woodhouse CRJ. Myelomeningocele: neglected aspects. Pediatr Nephrol. 2008;23(8):1223-31. doi:10.1007/s00467-007-0663-3

11. Bol KA, Collins JS, Kirby RS, National Birth Defects Prevention Network. Survival of infants with neural tube defects in the presence of folic acid fortification. Pediatrics. 2006;117(3):803-13. doi:10.1542/peds.2005-1364

12. Sayed AR, Bourne D, Pattinson R, Nixon J, Henderson B. Decline in the prevalence of neural tube defects following folic acid fortification and its cost-benefit in South Africa. Birth Defects Res A Clin Mol Teratol. 2008;82(4):211-6. doi:10.1002/bdra.20442

13. López-Camelo JS, Castilla EE, Orioli IM. Folic acid flour fortification: impact on the frequencies of 52 congenital anomaly types in three South American countries. Am J Med Genet A. 2010;152A(10):2444-58. doi:10.1002/ajmg.a.33479

14. Botto LD, Lisi A, Robert-Gnansia E, Erickson JD, Vollset SE, Mastroiacovo P, et al. International retrospective cohort study of neural tube defects in relation to folic acid recommendations: are the recommendations working? BMJ. 2005;330(7491):571. doi:10.1136/bmj.38336.664352.82

15. Ulsenheimer MMM, Antoniuk SA, Santos LHCD, Ceccatto MP, Silveira AE, Ruiz AP, et al. Myelomeningocele: a Brazilian University Hospital experience. Arq Neuropsiquiatr. 2004;62(4):963-8.. doi:10.1590/S0004-282X2004000600006

16. Faraji M, Ashrafzadeh F, Ariamanesh A, Faraji S. Surgical Outcome of Patients With Meningomyelocele Treated With a Team Approach. Neurosurg Q. 2006;16(2):85-8. doi:10.1097/00013414-200606000-00007

17. Althouse R, Wald N. Survival and handicap of infants with spina bifida. Arch Dis Child. 1980;55(11):845-50. doi:10.1136/adc.55.11.845

18. Bowman RM, McLone DG, Grant JA, Tomita T, Ito JA. Spina bifida outcome: a 25-year prospective. Pediatr Neurosurg. 2001;34(3):114-20. doi:10.1159/000056005

19. Piatt JH Jr. Treatment of myelomeningocele: a review of outcomes and continuing neurosurgical considerations among adults. J Neurosurg Pediatr. 2010;6(6):515-25. doi:10.3171/2010.9.PEDS10266
20. Oakeshott P, Reid F, Poulton A, Markus H, Whitaker RH, Hunt GM. Neurological level at birth predicts survival to the mid-40s and urological deaths in open spina bifida: a complete prospective cohort study. Dev Med Child Neurol. 2015;57(7):634-8. doi:10.1111/dmen.12698

21. Talamonti G, D’Aliberti G, Collice M. Myelomeningocele: long-term neurosurgical treatment and follow-up in 202 patients. J Neurosurg. 2007107(5 Suppl):368-86. doi:10.3171/PED-07/11/368

22. Sutton M, Daly LE, Kirke PN. Survival and disability in a cohort of neural tube defect births in Dublin, Ireland. Birth Defects Res A Clin Mol Teratol. 2008;82(10):701-9. doi:10.1002/bdra.20498

23. Botto LD, Mulinare J, Erickson JD. Occurrence of congenital heart defects in relation to maternal mulitivitamin use. Am J Epidemiol. 2000;151(9):878-84. doi:10.1093/oxfordjournals.aje.a010291

24. Barboza-Arguello ML, Benavides-Lara A, Umaña L, Vargas-Leitón B. [Infant mortality from birth defects in Costa Rica, 1981-2010]. Rev Panam Salud Publica. 2013;34(5):304-11. Spanish.

25. Tuli S, Tuli J, Drake J, Spears J. Predictors of death in pediatric patients requiring cerebrospinal fluid shunts. J Neurosurg. 2004;100(5 Suppl Pediatrics):442-6. doi:10.3171/ped.2004.100.5.0442

26. Charney EB, Melchionni JB, Antonucci DL. Ventriculitis in newborns with myelomeningocele. Am J Dis Child. 1991;145(3):287-90. doi:10.1001/archpedi.1991.02160030055020

27. Veenboer PW, Bosch JL, Asbeck FW, Kort LM. Upper and lower urinary tract outcomes in adult myelomeningocele patients: a systematic review. PLoS One. 2012;7(10):e48399. doi:10.1371/journal.pone.0048399

28. McLone DG. Results of treatment of children born with a myelomeningocele. Clin Neurosurg. 1983;30:407-12.

29. Tubbs RS, Oakes WJ. Treatment and management of the Chiari II malformation: an evidence-based review of the literature. Childs Nerv Syst. 2004;20(6):375-81. doi:10.1007/s00381-004-0969-4

30. Salomão JF, Bellas AR, Leibinger RD, Barbosa AP, Brandão MA. [Symptomatic Chiari type II malformation]. Arq Neuropsiquiatr. 1998;56(1):98-106. Portuguese. doi:10.1590/S0004-282X1998000100016

31. Salomão JF, Leibinger RD, Carvalho JG, Pinheiro JA, Lucchesi GL, Bomfim V. [Follow-up of myelomeningocele patients in the outclinic of a pediatric hospital]. Arq Neuropsiquiatr. 1995;53(3A):444-50. Portuguese. doi:10.1590/S0004-282X1995000300013 